JOURNAL OF MANAGEMENT (2021), VOL. 4(1), 16-30

\title{
The Initiator of Women and Their Reasons for Entry in Micro-Enterprises
}

\author{
Bandana Kumari Jain \\ Lecturer \\ Faculty of Management, Post Graduate Campus, Biratnagar \\ Tribhuvan University, Nepal \\ Email: bandana.jain@pgc.tu.edu.np \\ DOI: https://doi.org/10.3126/jom.v4i1.38659
}

\begin{abstract}
This paper aims to describe women and their enterprises and to assess the initiator, and their reasons behind the commencement of their business. The paper deals with the micro-enterprises controlled and managed by a disadvantaged section of women in Biratnagar Metropolitan City. The sample of 54 deprived women running microenterprises was selected implying a purposive sampling method. Primary data were collected with a structured questionnaire that was administered by the researcher. The study depicted that there were 3 main motivating factors self-motivation, selfemployment attitudes, and educational background of leaning towards microenterprises. The disadvantaged section of women due to various social inhibitions and personal reasons, there is a little chance of getting formal jobs in an organized sector. This compelled them to run micro-enterprises. Women belonging to disadvantaged classes are willing for productive involvement in economic gainful activities pushing them to micro-enterprises.
\end{abstract}

Keywords: women, micro-enterprise, reason for entry, initiation, entrepreneur

\section{Introduction}

\section{Background}

Different estimates of poverty measurement indicate that the majority of the population of Nepal is struggling with absolute poverty. The $15^{\text {th }}$ plan of Nepal reports 18.7 percent of the total population lie below the poverty line (National Planning Commission, 2020, p.5). Duflo (2012) states that economic strength mitigates the severity of poverty by the same time, it betters up the condition of everyone in the family. On the other hand, gender inequality declines in society as poverty slips down. 
Nepal is a multilingual, multi-religious, and multicultural country. Among the diversity, there are different castes and creeds. There are sundry disadvantaged groups of people in the country (Haque, 2013). These deprived groups enjoy lesser facilities such as education, health, training facilities like what other citizens of the country enjoy these facilities. These glass ceilings leg deprived people behind to grab equal opportunities for formal employment in the country. But the lack of opportunities in front of the disadvantaged group bound them to seek other ways for their and their dependents' livelihood. The informal sector is the mere alternate of their subsistence.

Women, traditionally, were confined to three Ks; kids, kitchen, and knitting. They were not free to go alone and on their own to visit places and meet people (Tuladhar, Khanal, KC, Ghimire \& Onta, 2013). In most cultures, female employment is discouraged in Nepal. There are two reasons to go for employment to women. Firstly, it is tough to run a family with single earning especially in urban (Tripp, 1989), and secondly, the desire to be economically independent is another drive for women's going to employment (Mayoux, 1995). This initiates women to become self-employed; it gives them self-fulfilment and an opportunity to prove themselves (Itani, Sidani \& Baalbaki, 2011). With the world becoming a global village, many women in a remote area are becoming exposed to the idea of financial independence, as a route to empowerment. Supporting family income and raising their standard of living are major contributors to women in entrepreneurship.

Eventually, the micro-enterprises remain as the last alternate for the subsistence of deprived ones because of their educational, social, financial assess constraints. GEM (2005) postulates that micro-enterprises are proved as a key driver and backbone for the countries with massive involvement of people in the self-employment sector. Mayoux (1995) envisages that the increasing number of women's access to micro-enterprises is not a conscious choice preferably, they do not have enough other possibilities for employment. ILO (2016) put forward that women long to be in the informal sector. All entrepreneurs have common systematic barriers, problems, and challenges of legal framework, laws, and regulations, social attitude, and mores that is why to avoid further harassment of formality of registration women entrepreneurs would stay in the informal economy.

Urban women now bear more responsibility for feeding their families than they did in the past. We need to explore their role as an agent of change within today's more dynamic household economy (Tripp, 1989), economic market, and social structure (Lu 
$\&$ Chen, 2013). There is a dearth of studies in the context of Nepalese disadvantaged women micro-entrepreneurs. Hence, this paper aims to understand the reasons to start micro-enterprises and initiators of underprivileged women's enterprises.

\section{Research Problems}

Urban women now bear more responsibility for feeding their families than they did in the past. We need to explore their role as an agent of change within today's more dynamic household economy (Tripp, 1989), economic market, and social structure (Lu $\&$ Chen, 2013). There is a dearth of studies in the context of Nepalese disadvantaged women micro-entrepreneurs. Hence, this paper aims to understand the reasons to start micro-enterprises and initiators of underprivileged women's enterprises.

In a nutshell, for the prosperity of any countrywomen and men are to be carried out together. Nepal is a country that is back in the realization of the very truth that is why; women of Nepal are to be initiated for their empowerment. It strikes some research questions;

- What are the elements that initiated women to start their micro-enterprises?

- What are the reasons for women to enter in micro-enterprises?

\section{Research Objectives}

The study primarily intends to identify the initiators (who helped to initiate their business) of women micro-entrepreneurs and their reasons to enter entrepreneurship of Biratnagar, Metropolitan. The specific objectives of the study are mentioned below;

- To identify the elements that initiated women to start a micro-enterprise in general

- To assess the reasons for women entering to micro-enterprise in particular.

\section{Research Limitations}

The following are the limitations of the study;

- This study is mainly based on the data collected from the primary sources. Therefore, the study naturally suffers from the inherent limitations of primary data.

- The sample size of the women studied in the study is relatively small in size.

- The findings of the study may not claim as the representative for entire women in micro-enterprises so may not able to generalize. 


\section{The Rationale of the Study}

This study seeks to examine what initiate women towards micro-entrepreneurs and what are the reasons to choose micro-entrepreneurship by the women from underprivileged sections. How micro-enterprises run by women uplifting women's level of earning together with enhancing their social status. Micro-enterprises are considered to be enabling women to enhance self-employment, self-respect, and social dignity by contributing to reduce poverty and break the vicious cycle of poverty. Therefore, the study contributes to understanding the role of micro-enterprises in enhancing women empowerment in the context of Nepal.

Women empowerment is still far behind success in Nepal despite various programs and policies by the government and I/NGO sectors. Thus, the findings of this research help I/NGOs and government or society as a whole in the understanding status of women micro-entrepreneurs. Specifically, women from disadvantaged sections of empowerment and help in rethinking and restructuring their existing policy and practices for the effectiveness of such programs.

\section{Literature Review}

This section thoroughly reviewed various studies and research papers relating to micro-entrepreneurs and especially in the context of women. This portion of the study highlights the need for the micro-enterprises, impediments of the women entrepreneurs, and women in the Nepalese context.

\section{Micro-Enterprises: Need of the Day}

In Nepal, micro-enterprise was defined as an economic entity that carries the features of self-employment, self-managed, employing 1-9 persons, fixed capital investment up to Rs 200,000 (excluding land and building), power machine (not exceeding 5 Kilo Watt), and no licensing requirement - Industrial Act, 1992 (Ministry of Industry [MOI], 1992).

Sidhu and Kaur (2006) stated that micro-enterprises were resembled as the stepping stone for industrialization by the world. People at the bottom of the pyramid probably could be benefited through micro-enterprises by widening their equity and stability. Micro-enterprises had induced people to participate in the development process (Mariadoss, 2012). Micro-enterprises were employment-generating sectors at low-cost capital. To promote economic development, micro-enterprises were assumed as the engine for triggered and sustained economic growth and equitable development 
in both developed and developing countries (OECD, 2004; Paramanandam \& Packirisamy, 2015). Therefore, micro-enterprises were also regarded as one of the hottest anti-poverty strategies (Gugliotta, 1993).

Meantime, studies stressed that micro-enterprises were very sensitive and vulnerable to socio-economic changes that were why few could only sustain for more than five-six years (Audet \& Jean, 2007). Micro-enterprises were managed by low income, women, or minorities; generally, they were excluded from formal credits as they had poor credit histories inadequate collateral (Clark \& Huston, 1992).

\section{Women Entrepreneurs and Impediments on their Way}

A study on many countries by Htun and Weldon inferred that there was discrimination among male and female regarding inheritance. Women still lacked independent rights to own land, manage the property, conduct business, or even travel without their spouse's consent. It had a direct impact on women's ability to participate in economic activities and certainly lessen bargaining power within the household and society.

However, Buttner \& Moore (1997) depicted that women were more likely to start their enterprises for the challenges and personal growth leaving their management positions. Career dissatisfaction and child-rearing were found to be chief reasons to start women-led businesses. In an empirical study of Shiralashetti (2011) revealed that self-employed women optimally mobilized and utilized local resources. The study disclosed that women were more productive in many aspects of entrepreneurial activities in comparison to men. Similarly, Paramanandam \& Packirisamy (2015) revealed that the income earned by women solely went into the maintenance of their home, as compared to men, for whom only a part of the earning was spent in the development of the home. Ironically, The World Bank (2000) dictated in the research literature because of ethnicity, caste, religion, and other factors, women experience multiple discrimination and exclusion, and persistent gender inequality in the society.

Due to prevailing discrimination and inequality against women engendered some additional challenges to them as entrepreneurs moreover it became severe when it was associated with ethnicity (The World Bank, 2002). Amine \& Staub (2009) concluded that any meaningful generalizations about ethnicity and entrepreneurship were tough to draw as there were very few studies and these studies had conflicting results. 
However, the study of Dzisi (2008) in Africa stated that indigenous small and micro-enterprises were the backbone of the successful growth and development of the African economy. Amine \& Staub (2009) added that indigenous respondents were comfortable with their self-identity but the results by the country vary considerably on ethnicity.

\section{The Entrepreneurial Stimulus of Women}

While discussing women's reason to start micro-enterprises research had widely discussed push and pull factors. Ducheneaut (1997) had categorized insufficient family income, dissatisfaction with the salaried job (Ahmed, 2011), difficulty in finding work, and a need for a flexible work schedule were push factors that motivate women for selfemployment. Because women were laden with family and social responsibilities. Whereas, as mentioned in the research work of Ramadani, Gerguri, Dana \& Tasaminova (2013), the common motivators of women entrepreneurs as postulated by Hisrich \& Brush (1986) were: independence, job satisfaction, success, opportunities, status, money, power, and economic needs and secure career to undergo for selfemployment. Independence, self-fulfillment, entrepreneurial drive, desire for wealth, social wealth, and power are push factors that guide them to lead their venture.

Bushell (2008) found pull factors as one of the most vigilant motivating factors of women entrepreneurs, secondly, poor financial circumstances of the family and finally by chance women had been in self-entrepreneurship. Similarly, a study conceded that in general pull factors stand more rigorous than push motivating factors of entrepreneurship (Wang, Walker \& Redmond, 2006).

\section{Women in the Nepalese Context}

A common framework for action by the UN system in Nepal stated social transformation was solely feasible by social inclusion which was a foremost national agenda for the government of Nepal. To introduce marginalized and excluded groups and communities such as Dalit, Janajati, Madeshis, religious minorities, disables, people from remote regions, sexual minorities, women, children, senior citizens, and poor into the mainstream on equal terms with all other citizens, the government was propelled and committed for flux. Bhattanchan (2002) manifested that gender discrimination was dreadful in Nepal but such discrimination's intensity, degree, forms, and nature differed by women's ethnicity, religion, and culture. Hence, this engendered a different level of victimization of one type of woman to another. Indigenous and Dalit 
women underwent multiple victims like gender discrimination and marginalized by ethnicity, language, culture, and religion. Similarly, Muslim women are supposed to be cheated in the name of religion, social customs, and traditions (Giri, 2006). Muslim is a religious minority of Nepal that covers approximately 4.4 percent of the total population.

Gurung (2008) affirmed the changes realized in women's status and rights, particularly in developing countries like Nepal, was marginal. While Thapa (2012) insisted on the paucity of skills and capital that threw women especially Dalit, Indigenous, and poor back, and to commence their enterprise because review reflected that discrimination based on caste, sex and ethnicity existed in the Nepali society.

\section{Research Methods and Materials}

The study aimed to describe women micro-entrepreneurs and their enterprises together with the initiators and the reasons to start micro-enterprises. This section of the study overwhelmed research design, population and sample description, sources, and methods of data and data collection, data analysis.

\section{Research Design}

Underprivileged and minority groups like Dalit, Aadiwasi (Indigenous), and Muslim women were chosen for the study. Therefore, the descriptive research design implied to get the objectives; the reason to start a micro-enterprise and initiator of their entrepreneurship of the study.

\section{Sources of Data}

Micro-enterprises are always a non-registered and beyond the tax-reach so that it is not possible to identify the exact number of it. The study was confined to disadvantaged women especially Dalit, Muslim, and Aadiwasi (Indigenous) involved in micro-enterprises from Biratnagar, Metropolitan. The lack of up-to-date and comprehensive data on micro-enterprises was a common problem, to a greater or lesser extent, throughout the world (World Bank, 2000). Both primary and secondary sources of data were harnessed for the study. The secondary data included information obtained mainly from different reports, bulletins, websites, and literature that had been relevant to the theme of the study, gathered from various sources to complement the surveybased analysis. 


\section{Population and Sample}

Secondary data had been extracted to identify and frame the sample. Some concerning agencies like MEDPA (Micro Enterprise Development for Poverty Alleviation) and other microfinance institutions, working in the finance sector, were visited for getting the necessary information. They were asked to identify the required women respondents that resulted in 54 disadvantaged Muslim, Indigenous (Aadiwasi), Dalit women running their micro-enterprises in Biratnagar, Metropolitan.

\section{Sampling Method}

Purposive sampling method was harnessed to spot respondents because some of the women belonging to these communities were found reluctant to share their information.

\section{Data Collection Tool}

The study was based on primary data. For the purpose, a structured questionnaire was used. The questionnaire contained two sections with closed-ended questions. The first section dealt with personal and the enterprises' basic information. And the second portion included 'initiator for their enterprises' which was a single choice question and 'reason/s to choose entry micro-enterprise' which was a multiplechoice question. The questionnaire was extracted from Acharya (2002) and Wube (2010). Initially, the questionnaire was prepared in the English language later taking into account the respondents' educational background, and to increase understandability it was translated into Nepali so had been convenient for respondents to deal with.

\section{Data Collection Method}

To collect information, a structured questionnaire was administered by the researcher on self after asking the questions enlisted in it. As per the convenience of women wherever and whenever either their home or farm or shop and time arranged and set as per respondents' comfortability. This approach was used to get the proper and authentic information on the question assuming low academic background of the respondents.

\section{Methods of Data Analysis}

After the data had been collected, the responses on the questionnaire survey were categorized, tabulated, processed, and analyzed and with the help of SPSS 20. 
Descriptive statistical tools were implied to achieve the intent of the study. Methods of data analysis were percentage and multiple response analysis.

\section{Reliability and Validity}

To ensure the content validity of the instruments, previously developed and tested set of questionnaires were used. Besides, to ensure context validity, the study had combined and modified the different sets of questionnaires following place of residence, level of education, the difference in religion and culture, and other factors of the required respondents. After combining relevant questions for the study, the questionnaire was overviewed by the experts, and the necessary corrections were made according to the suggestions and comments given by the experts. It referred to the subjective agreement among professionals that a scale logically appeared to accurately measure what was intended to measure (Zikmund, 2003). Initially, it was pretty tough to collect responses of women entrepreneurs of these deprived groups so that motivators (who collect funds and motivate people to save, to take a loan) of microfinance institutions helped. And other entrepreneurs in that locality were accumulated by the assistance of members of microfinance. They had more ideas about the areas as these motivators had gone for collecting installment by women from the nooks and corners of Biratnagar city. More than one attempt was made to contact the respondents to get their responses to the questionnaire because of their busy schedules.

\section{Results and Discussion}

This part of the study attempts to describe women micro-entrepreneurs and their enterprises, the factors that initiated them for commencing their business, and their reasons to start their business.

\section{Table 1}

Descriptive Statistics of the Respondents and their Enterprises

\begin{tabular}{llll}
\hline Variables & Categories & Frequency & Percent \\
\hline Women ME caste & Dalit & 24 & 44 \\
& Aadiwasi & 20 & 37 \\
& Muslim & 10 & 19 \\
\hline \multirow{2}{*}{ Women ME education } & Illiterate & 36 & 67 \\
& Below SLC & 11 & 20 \\
\hline
\end{tabular}




\begin{tabular}{llll}
\hline & SLC and above & 07 & 13 \\
\hline Enterprise category & Manufacturing & 4 & 08 \\
& Service & 20 & 37 \\
& Trading & 19 & 35 \\
& Farming & 11 & 20 \\
\hline Years of enterprise & $1-5$ & 25 & 45 \\
& $6-10$ & 13 & 25 \\
& 11 and above & 16 & 30 \\
\hline
\end{tabular}

Note. Field Survey, 2019.

Table 1 depicts that out of the total respondents nearly half of the microentrepreneurs were Dalits while very few almost one-fifth of micro-entrepreneurs were Muslim. Two-thirds of micro-entrepreneurs were uneducated. A nominal percent of micro-entrepreneurs was completed their standard tenth and above. On the contrary, Nasima \& Alam (2014) found that educated women were more likely to start their own business. More than half of sampled Bangladeshi women micro-entrepreneurs had completed their post-graduate level.

Service-oriented businesses and trading outlets had attracted micro-entrepreneurs. Contradictorily, Wube (2010) found more than half of women entrepreneurs were in the production and service sector were second in the ranking. Women usually tended to choose "pink-collar" businesses low capitalized, small scale, and barely profitable and running a business from home. Women keenly focused on that work that related to their daily gender-specific role (Ehlers \& Main, 1998). Similarly, Nepalese women are also more likely to go with home-based enterprises as they are chained with financial, social, knowledge and network, role-bounded constraints.

There were more new entrants in micro-enterprises, as half of the microentrepreneurs had commenced their venture within 5 years. Likewise, Nasima and Alam (2014) found 38 percent, and Wube (2010) found 76 percent of women microentrepreneurs commenced their business within five years. The case was different in Biratnagar, many women were leaving their jobs and commencing their enterprise. Sometimes back, they were recognized as idle and spare but the time had revolved. Women were engaged in full-time basis projects like micro-entrepreneurs (Tripp, 1989). There is a long history of disadvantaged women in micro-enterprises. About 
one-third of respondents were involved in their enterprises for/more than 11 years back. Likewise, Wube (2010) extracted that 20 percent of entrepreneurs were commenced their business more than 10 years back.

\section{Table 2}

Descriptive Statistics of Initiation and Reasons for Entering Micro-Entrepreneurs

\begin{tabular}{llll}
\hline Variables & Categories & Frequency & Percent \\
\hline Initiator of ME & Family tradition & 05 & 09 \\
& Father/in-law & 02 & 04 \\
& Mother/in-law & 02 & 04 \\
& Husband & 09 & 16 \\
& Self & 36 & 67 \\
\hline Reasons for ME entry & Family tradition & 08 & 15 \\
& Self-employment & 36 & 67 \\
& Make money & 18 & 33 \\
& Support family & 04 & 07 \\
& No other option & 11 & 20 \\
& Social prestige & 02 & 04 \\
\hline
\end{tabular}

Note. Field Survey, 2019.

Table 2 displays that most of the micro-entrepreneurs were self-motivated to initiate their own business. The husband was the next initiator for the respondents. Similarly, Wube (2010) found more than half of the respondents were self-motivated to initiate their micro-enterprise. Little differently, self, family tradition, and spouse are consecutively forced to start their enterprise (Jain, 2017). Self-initiation was the vital cause to go with his enterprises. In developing countries, micro-enterprises comprised the vast majority of the small business sector. These micro-entrepreneurs probably most micro-enterprises were not operated by choice, but out of necessity (Paramanandam \& Packirisamy, 2015).

Reasons to start micro-enterprises were a multiple-answer question with six reasons. Hence, the multiple response analysis was used to identify the most effective one among the reasons. The most effective reason was 'self-drive' to become selfemployed. Due to the weak economic background, 'money-making' and 'no other option' stood second and third reasons to commence their own business respectively. Alike, Jain (2017) displayed that 'self-employment', 'make money', and 'family 
tradition' respectively had an apparent reason for starting micro-enterprises. 'No other option', 'self-employment', and 'family tradition' remained serially important reasons for micro-entrepreneurs (Wube, 2010). Nasima and Alam (2014) resulted that 'do not want to work for others', 'money-making', and 'family crisis' accordingly as the cause of starting own business. Inline, Das (2000) had suggested 'forced entrepreneurs', these were bounded by the financial condition of the family and so forced to follow entrepreneurship.

\section{Conclusion}

The informal economy of Nepal covers 70 percent of the economically active population. Micro-enterprises run in the informal sector. In general, micro-enterprises are a mere option for the poor and uneducated ones. They have no room in the formal sector employment mainly because of the absence of a formal education degree. When these problems like literacy and poverty come to women, especially belong to deprived classes, the severity hikes up. Nearly half of the female population of Nepal is illiterate and that limits the employment opportunities to them. The accessibility to finance and the procedures and knowledge about registration of their venture is very challenging to women. Therefore, going to the micro-businesses is only the leftover option for disadvantaged women.

Nepal is a male-dominated society where the work is segregated according to gender. The domestic chores and children rearing are the primary responsibilities of women as set by society. Women can dream of their engagement in any other activity after managing their foremost tasks. Hence, with the remaining time in hand, women are only eligible for entrepreneurship. Women want to be their boss so that they can easily and accordingly cope with their major problems together with their desire to do something productive. Though they have minimal chances of getting employment, their involvement in micro-enterprises is their self-initiation. The staple reason behind women's drive for micro-enterprises is their desire for productive involvement in economic gainful activities. Commencement of own micro-enterprise, to some extent, helps to empower women economically that leads to filling the gap between gender inequality.

\section{References}

Acharya, V. R. (2000). Socio-economic effects of industrial employment in Nepal. [Unpublished Ph.D. Thesis]: Lucknow University, India. 
Ahmad, S. Z. (2011). Evidence of the characteristics of women entrepreneurs in the Kingdom of Saudi Arabia. International Journal of Gender and Entrepreneurship, $3(2)$.

Amine, L. S. \& Staub, K. M. (2009). Women entrepreneurs in sub-Saharan Africa: An institutional theory analysis from a social marketing point of view.

Entrepreneurship \& Regional Development: An International Journal, 21(2), 183211. DOI: $10.1080 / 08985620802182144$

Audet, J . \& Jean, S. (2007). Factors affecting the use of public support services by SME owners: Evidence from a periphery region of Canada. Journal of Developmental Entrepreneurship, 12(2), 165-181.

Bhattanchan, K. B. (2002). Indigenous peoples and minorities of Nepal.

Bushell, B. (2008). Women entrepreneurs in Nepal: what prevents them from leading the sectors? Gender and Development: Oxfam. 16(3).

Buttner, E. H. \& Moore, D. P. (1997). Women's organizational exodus to entrepreneurship: self-reported motivations and correlates with success. Journal of Small Business Management, 35(1), 34-46.

Clark, M., Huston, T., \& Meister, B. (1992). Directory of microenterprise programs. Washington, DC: The Aspen Institute.

Das, D. J. (2000). Problems faced by women entrepreneurs. In K. Sasikumar (ed.). Women Entrepreneurship: New Delhi, Vikash Publishing House.

Ducheneaut, B. (1997). Women entrepreneurs in small and medium enterprises: A major force for innovation and job creation. Paris: Report Created for OECD Conference.

Duflo, E. (2012). Women empowerment and economic development. Journal of Economic Literature. 50(4), 1051-1079. http://dx.doi.org/10.1257/jel.50.4.1051

Dzisi, S. (2008). Women entrepreneurs in small and medium enterprises (SMEs) in Ghana. Australia: University of Technology Victoria.

Ehlers, T. B. \& Main, K. (1998). Women and the false promise of microenterprise. Gender and Society, 12(4).

GEM. (2016). Global Report 2016-17. Global Entrepreneurship Monitor.

Giri, N. (2006). Laws Institution and Women Rights in India” in laws institution and Women Right in India (ed) by Tapan Biswal, Viva books: New Delhi. 
Gugliotta, G. (1993, May 6). Harvesting a living from seeds of credit: Anti- poverty strategy called microenterprise is growing in US. Washington post.

Gurung, H. (2002). Janganana 2001 Anusar Jatiya Tathyanka Prarambhik Lekhajokha (Preliminary Assessment of Ethnic Data based on the Census - 2001 A.D.), Kathmandu: Dharmodaya Sabha, Text in Nepali.

Haque, Z. (2013). Muslims cultural and religious practices as a minority group, 41-44. https://doi.org/10.7763/IPEDR.

Hisrich, R. D. \& Brush, G. C. (1986). The Woman Entrepreneur: Starting, Financing and Managing a Successful new Business. Massachusetts: Lexington Books.

International Labour Organisation. (2016). Women at work trends 2016. International Labour Organization: Geneva.

Itani, H., Sidani, Y. M., \& Baalbaki, I. (2011). United Arab Emirates female entrepreneurs: motivations and frustrations. Equality, Diversity and Inclusion: An International Journal.

Jain, B. K. (2017). Women's socio-economic empowerment through micro-enterprises in Biratnagar City (Focusing on Dalit and Indigenous women), [Unpublished MPhil Thesis], Tribhuvan University, Nepal.

Lu, W. C. \& Chen, W. H. (2013). A study on female entrepreneurs' behavior in microenterprises in Taiwan: An application of planned behavior theory. The Journal of Global Business Management, 9(1).

Mayoux, L. (1995). Jobs, Gender and Small Enterprises: Getting The Policy Environment Right from Vicious to Virtuous Circles? (Occasional paper No. 3). United Nations Research Institute for Social Development United Nations Development Programme.

MOI. (1992). Industrial enterprises Act 1992. Ministry of Industry, Government of Nepal.

Maridoss, S. (2012). Women empowerment through micro enterprises. International Journal of Physical and Social Science, 2(3).

Nasima \& Alam, N. (2014). Women micro-entrepreneurs in Bangladesh: Socioeconomic aspects and factors affecting their development. Journal of Business and Technology (Dhaka), 4(1).

National Planning Commission. (2020). 15 ${ }^{\text {th }}$ Planning Fiscal Year 2076/77-2080/81. National Planning Commission: Kathmandu. 
Organization for Economic Cooperation Development. (2004). Women's Entrepreneurship: Issues and policies. Paris: OECD Publishing.

Paramanandam, D. A. \& Packirisamy, P. (2015). An empirical study on the impact of micro enterprises on women empowerment. Journal of Enterprising Communities: People and Places in the Global Economy, 9(4), 298-314.

Ramadani, V., Gërguri, S., Dana, L. P. \& Tašaminova, T. (2013). Women entrepreneurs in the Republic of Macedonia: Waiting for directions. International Journal Entrepreneurship and Small Business, 19(1), 95-121.

Shiralashetti, A. S. (2011). Empowerment of women in gadag district - A study of self help groups entrepreneurs. International Journal of Research in Computer Application \& Management, 1(1), 138-144.

Sidhu, K., \& Kaur, S. (2006). Development of entrepreneurship among rural women. Journal of Social Sciences, 13(2), 147-149.

Thapa, P.K. (2012). Analytical summary of research report. MEDEP, 2.

Tripp, A. M. (1989). Women and the changing urban household economy in Tanzania. The Journal of Modern African Studies, 27(4), 601-623. doi:

10.1017/S0022278X00020462

Tuladhar, S., Khanal, K. R., K.C., L., Ghimire, P.K. \& Onta, K. (2013). Women's empowerment and spousal violence in relation to health outcomes in Nepal. Kathmandu: USAID.

Wang, C., Walker, E. A. \& Redmond, J. (2006). Ownership motivation and strategic planning in small business. Journal of Asia Entrepreneurship and Sustainability, 11(4). www.asiaentrepreneurshipjournal.com

World Bank. (2000). SME Facts Country Mapping. New York: The World Bank Group SME Department, 1(7).

Wube, M. C. (2010). Factors affecting the performance of women entrepreneurs in micro and small enterprises. The case of Dessie Town, [Unpublished MA Thesis], Bahir Dar University, Ethiopia.

Zikmund, W.G. (2003). Business Research Methods (7th ed.). Ohio: Thomson Learning South-Western. 